TITLE:

\title{
Elastic and inelastic scattering of 34.4 MeV alpha particles by [58] $\mathrm{Ni}$ and [60] $\mathrm{Ni}($ Abstract_要旨 )
}

AUTHOR(S):

Inoue, Makoto

\section{CITATION:}

Inoue, Makoto. Elastic and inelastic scattering of 34.4 MeV alpha particles by [58] $\mathrm{Ni}$ and [60] Ni. 京都大学, 1968, 理学博士

ISSUE DATE:

1968-11-25

URL:

http://hdl.handle.net/2433/213017

RIGHT: 


\section{【 54 】}

氏 名

学位の種 類 学位記番号 学位授与の日付 学位授与の要件 学位論文題目
井少の方信

理学 博 士

論 理 博 第 258 号

昭 和 43 年 11 月 25 日

学位規則第 5 条第 2 項該当

\section{Elastic and inelastic scattering of $34.4 \mathrm{MeV}$ alpha particles by ${ }^{58} \mathrm{Ni}$ and ${ }^{60} \mathrm{Ni}$}

$\left({ }^{58} \mathrm{Ni}\right.$ および ${ }^{60} \mathrm{Ni}$ よる $34.4 \mathrm{MeV}$ アルファ粒子の弾性および非弾 性散乱)

論文調查委員教授武藤二郎教授小林稔教授柳父琢治

\section{論交内容 $の$ 要旨}

原子番号がニッケルの前後の偶々核においてはその基底状態を含めてスピンおよび偶奇性がそれぞれ $0^{+}, 2^{+}, 3^{-}, 4^{+} \ldots \cdots$ 準位が順次に下から存在し, その第 1 励起準位の約 2 倍のエネルギーの位置に極め て接近した $4^{+}, 2^{+}, 0^{+}$の三つの準位がみられ，とれらは原子核の集団運動模型の立場から 2 フォノン（音 子) の状態といわれている。

一般に，原子核の集団励起準位を実験的に調べるに当たっては，その原子核による $\alpha$ 粒子の非弾性散乱 の角分布を解析することが Blair 達の成功以来極めて有効な手段であるとされてきているが，との 2 フォ ノン準位については単純な解析方法の適用できないてとがわかってきた。

申請者は東京大学原子核研究所のサイクロトロンから得られる $34.4 \mathrm{MeV} の \alpha$ 粒子を用いて, ${ }^{58} \mathrm{Ni}$ お よび ${ }^{60} \mathrm{Ni}$ の原子核によって散乱された $\alpha$ 䊉子のエネルギースペクトルを種々の角度で測定し，てれらの 原子核の約 40 個におよふ励起準位に対応する $\alpha$ 粒子非弾性散乱の角分布を測定した。その際, $40^{\circ}$ より前方 の場合は精度の高い電磁石方式スペクトロメーターを用い, $40^{\circ} \sim 60^{\circ}$ の間は固体検出器を用いたが，それ らのエネルギー分解能は約 $0.2 \%$ ，従来の $\alpha$ 粒子非弾性散乱の実験では分解し得なかった第 2 励起準位の トリプレット $4^{+}, 2^{+}, 0^{+}$をく分解して测定することに成功し，それらの個々の準位に対応する角分布を 得ることができた。また従来の実験では見出されていなかった多くの準位についても明確な角分布の形を 得るととに成功した。

とれらの角分布から準位の性質を解析するために，まずディフラクション・モデルの方法を適用し，さ らに定量的に評価を行なうために弾性散乱角分布からその原子核の光学的ポテンシャルのパラメーターを 決定し，そのポテンシャルを用いて多くの非弾性散乱角分布の解析を行なういわゆる電曲波ボルン近似の 方法を適用した。乙れによって多くの準位についてのスピンと偶奇性を決定し，いくつかの準位について はそのデフォーメーション・パラメーターを算出した。

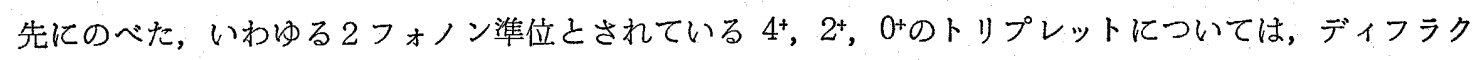


ション・モデルの解析で $4^{+}, 0^{+}$はいずれも 1 フォノとした場合にほぼ合致し，2+ $2^{+}$はフォノン的では あるが完全には 2 フォノンに合致しないととが判明した。申請者のとの実験結果は独立にオークリッジ研

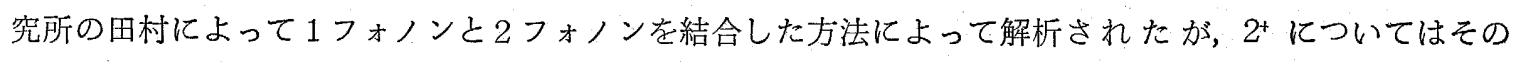
角分布の奏験值との一致はよくない。田村の計算から導出されたデフォメーション・パラメーターは申請 者がディフラクション・モデルの解析から求めたものと定性的によく合うので, 申請者はこの二つの解析 方法の相違をてえて，いわゆる2フォノン準位に対するフォノン模型の適用自体に疑問があるのではない かと考えている。とのととは最近の原子核構造理論の進展に扔いてフォノン模型执よびフォノン概念の有 用性について種々の点で疑惑がもたれ始めているてとと軌を一にしている。

最近の原子核構造に対する理論的解析は次第に精密化し, マクロスコピックな集団運動だけでなく, 原 子核のミクロな構造をとりいれた理論が発展しつつある。Veje らはてのような立場からの理論的計算に によって 8 極振動に相当する $3-$ 準位の現われるべきエネルギー值と，そのとるべきオッシレーター・ス トレングスの予想値を導出している。申請者が実験的に見出した多くの3一準位のうち, 強度の弱い準位を 除外すると, ${ }^{58} \mathrm{Ni} の 4.45 \mathrm{MeV}$ および $6.8 \mathrm{MeV}$ 準位, ${ }^{60} \mathrm{Ni}$ の $4.04 \mathrm{MeV}$ および $6.16 \mathrm{MeV}$ 準位はいずれ あエネルギー值抒よびオッシレーター・ストレングスの点でVeje の予想值に相当するものである。ての ことは定量的にはなお不十分な点むあるが，主要な準位については原子核構造のミクロスコピックな立場 からの理論の有効性を補強するあのというべきである。

\section{論 文 審 查の 結 果の 要 旨}

原子核の構造については種々の模型が提起され，その励起準位の解釈が行なわれている。中重核の励起 準位の中のあるものは原子核構成核子の集団運動に基因する原子核の表面振動としててこ10年来定量的に あ実験と一致する説明が行なわれてきた。この振動のエネルギーは量子化されてフォノン（音子）とよば れ，原子核の集団運動励起状態としてのフォノン準位が確立されている。

ニッケル付近の偶々核に执ける第 2 励起準位は従来から 2 フォノン状態といわれていたが，申請者はこ の定説に対して実験的な解明を行ない，乙れの準位は単純なフォノン模型とはよく適合しないととを示 しまた他の多くの準位についてすその解釈にはより微視的な原子核構造をとりいれた理論が要請される ととを示した。

すなわち，申請者は原子核 ${ }^{58} \mathrm{Ni} ，{ }^{60} \mathrm{Ni}$ による $\alpha$ 粒子非弾性散乱の精度のよい実験を行ない，従来の実 験では分解して測定し得なかったいわゆる2フォノン状態の三重線を分離して测ることに成功し，てれら の状態を励起する $\alpha$ 粒子の非弾性散乱微分断面積を系統的に解析した結果, これらの三重線はいずれる 単純に 2 フォノン励起と仮定した計算とは適合しないことを示した。更に申請者は同じ実験で得られた総 計40に及3゙励起準位についても解析を加え，従来知られていなかったスピンおよび偶奇性が 5-，6+ など の準位を見出したが，特に多く見出された 3-の準位について詳細な解析を加え，Veje らがマクロスコ ピックな集団運動にミクロスコピックな核構造の観点を加えて理論的に導出したエネルギーおよびオッシ レーター・ストレングスと定量的にほぼ合致する励起準位が現実にあるととを明示した。

最近の核構造理論はミクロスコピックな精密化の方向をとっているが, 申請者の実験的研究は原子核構 
造模型の精密化によって一つの焦点となっていた問題に対して実験的測定の精密化を行なうことによって 応えたすのであり，多くの新しい実験事実を加えたととと共に，原子核研究の進展に寄与する所が大き い。よって本論文は理学博士の学位論文として価值があるものと認める。 